\title{
Temperature-Sensitive Wheat streak mosaic virus Resistance Identified in KS03HW12 Wheat
}

D. L. Seifers, Professor, and T. J. Martin, Professor, Kansas State University Agricultural Research Center-Hays, Hays 67601; T. L. Harvey, Professor, Department of Entomology, Kansas State University, Manhattan 66506; and S. Haber, Cereal Research Center, Agriculture \& Agri-Food Canada, Winnipeg, Canada

\begin{abstract}
Seifers, D. L., Martin, T. J., Harvey, T. L., and Haber, S. 2007. Temperature-sensitive Wheat streak mosaic virus resistance identified in KS03HW12 wheat. Plant Dis. 91:1029-1033.

Wheat streak mosaic virus (WSMV) infection reduces seed yield and quality in wheat. These losses can be alleviated significantly by exploiting genetic host plant resistance. A new source of temperature-sensitive resistance to WSMV, KS03HW12, and its parental lines (KS97HW29/ KS97HW131//KS96HW100-5) were evaluated in both greenhouse and field conditions. Parental wheat lines were exposed to WSMV pressure under different temperatures in growth chambers to determine the stability of the resistance, and 2 years of field yield trials were conducted to confirm effectiveness. To determine the effectiveness of its resistance against a spectrum of isolates, KS03HW12 was tested against six different WSMV isolates of different geographic origins. Among the three pedigree parents, only one, KS97HW29, was resistant. The parental lines of KS97HW29 are not available for testing; therefore, the presumed origin of the resistance could not be further confirmed. None of the six tested WSMV isolates systemically infected KS03HW12 at $18^{\circ} \mathrm{C}$. Yield of KS03HW12 in field tests was not different from healthy controls. Thus, the elite winter wheat KS03HW12 appears to be a stable and effective source of temperature-sensitive resistance to WSMV and should be useful for wheat breeding programs.
\end{abstract}

Wheat streak mosaic virus (WSMV) causes wheat streak mosaic in wheat and is transmitted by the wheat curl mite (WCM) Aceria tosichella Keifer (12). Wheat streak mosaic is a serious disease of wheat in Kansas and can result in losses of $13 \%$ of the value of the wheat crop $(3,11,15)$.

Low levels of resistance or tolerance to WSMV have been identified in wheat and are available in elite germplasm, but such lines still suffer significant yield losses under high WSMV pressure (8). A higher, albeit temperature-sensitive, level of resistance to WSMV has been demonstrated for KS96HW10-3 germplasm derived from Thinopyrum intermedium $=$ Agropyron intermedium Barkworth \& D. R. Dewey subsp. intermedium (9). This resistance is effective at 20 but not $25^{\circ} \mathrm{C}$ in growth chamber tests (9). Unfortunately, no one has successfully incorporated the Thinopyrum source of resistance into a released cultivar. Another temperature-sensitive source of resistance to WSMV has been

Corresponding author: D. Seifers

E-mail: dseifers@ksu.edu

Contribution No. 07-101-J from the Kansas Agricultural Experiment Station, Manhattan, KS 66506. Research was supported in part by a grant from the Kansas Wheat Commission.

Accepted for publication 26 March 2007.

doi:10.1094/PDIS-91-8-1029

(c) 2007 The American Phytopathological Society identified from the registered elite germplasm CO960293 (2). Its resistance has proven effective in the field and it also has acceptable agronomic and quality traits (10). In 2006, cv. RonL, which contains the resistance from CO960293, was released to Kansas wheat growers.

In 2004, KS03HW12 (KS97HW29/ KS97HW131//KS96HW100-5) wheat being screened under WSMV pressure in greenhouse trials failed to produce foliar symptoms following mechanical inoculation with WSMV. This apparent resistance was confirmed by negative results in mechanical infectivity back-assays to susceptible wheat and by uniformly negative results in enzyme-linked immunosorbent assay against WSMV antiserum.

We report here our work to characterize the effectiveness of temperature-sensitive resistance to WSMV in KS03HW12 wheat under growth chamber and field conditions.

\section{MATERIALS AND METHODS}

Sources and maintenance of WSMV isolates. The CM93, El Batán-3, IHC, LG92, ND, Sidney 81, and WO93 isolates of WSMV were used in these studies. Details concerning these isolates are shown in Table 1. Virus isolates were increased in the susceptible wheat cv. Tomahawk by mechanically inoculating the first leaf using the finger-rub techniques previously described (7). Following inoculation, the wheat was held for 2 weeks in a growth chamber at 20 to $22^{\circ} \mathrm{C}$ with $8 \mathrm{~h}$ of illumi- nation $\left(250 \mu \mathrm{E} \mathrm{s} \mathrm{s}^{-1} \mathrm{~m}^{-2}\right)$ per day. The WSMV-infected symptomatic plant tissue then was frozen at $-80^{\circ} \mathrm{C}$ until needed. Throughout the experiments, inoculations were done using thawed portions of the frozen tissue using a method described previously (10). Briefly, the inoculum was prepared by grinding the tissue in a mortar and pestle at a 1:10 (wt/vol) dilution in $0.02 \mathrm{M}$ potassium phosphate buffer $(\mathrm{pH} 7)$. The ground extracted tissue then was filtered through cheesecloth, and $1 \mathrm{~g}$ of abrasive (Crystolon flour B", 600 mesh; Norton Co., Worcester, MA) was added for each $100 \mathrm{ml}$ of inoculum.

Infectivity assays. Tomahawk wheat was used as the susceptible host and mechanically inoculated at the single-leaf stage with 1:5 wt/vol extracts prepared from different wheat lines as described above. Inoculated plants were held in a greenhouse under natural lighting and rated for numbers of symptomatic plants at 14 days post-inoculation (DPI).

WSMV infectivity testing of KS03HW12, pedigree parents, and other wheat lines. The wheat lines or cvs. RonL, KS97HW131, KS03HW12 (2004 source), KS97HW29, KS96HW100-5 (1996 source), Triumph 64, CO960293, and three reselections from KS03HW12 (KS03HW12-1, KS03HW12-4, and KS03HW12-6) were planted into 30-by-50-cm soil-filled metal flats at 10 seeds per row for each entry. Two sets of this planting were done to provide plants for the 18 and $24^{\circ} \mathrm{C}$ temperature treatments. All plants were held in a growth chamber at $18^{\circ} \mathrm{C}$ until they were at the single-leaf stage and then mechanically inoculated as described above on the first leaf with a 1:10 wt/vol dilution of the Sidney 81 isolate of WSMV. This isolate was used to provide continuity with previous investigations $(9,10)$. The plants then were placed immediately in growth chambers at either 18 or $24^{\circ} \mathrm{C}$. At $14 \mathrm{DPI}$ for the $24^{\circ} \mathrm{C}$ treatment, all symptomatic tissue of the third leaves were bulked (within a wheat line) and ground separately in 0.02 M KPO4, pH 7, buffer at a 1:5 wt/vol dilution. From this 1:5 dilution, serial dilutions of $1: 25,1: 125$, and 1:625 were made. At $21 \mathrm{DPI}$ for the $18^{\circ} \mathrm{C}$ treatment, all symptomatic tissue of the third leaves was processed as described for the $24^{\circ} \mathrm{C}$ treatment. The extracts prepared from the tissue harvested at 18 and $24^{\circ} \mathrm{C}$ were used to inoculate Tomahawk wheat (single-leaf stage) as 
described above. The inoculated Tomahawk infectivity assay plants were held in a greenhouse under natural lighting (temperatures ranged from 20 to $31^{\circ} \mathrm{C}$ ) before they were rated for numbers of symptomatic plants at 14 DPI. The experiment was repeated three times. Data expressed as percentages were transformed with the arcsine transformation before analysis of variance (ANOVA) because the differences in percentages among treatments was greater than 40 percentage points (4); untransformed data are presented. The ANOVA for the data was conducted using SAS and significant treatment effects were determined using the least significance difference (LSD) at $P=0.05$.

All plantings in this study and other experiments conducted during these investigations used a Harney clay loam (fine montmorillonitic, mesic Typic Argiustoll) soil.

Wsm1 gene probe. Healthy wheat leaves of KS96HW12-6 and KS96HW10-3 were tested for the presence of the J15 (SCAR) DNA marker, described as tightly linked to the wsml resistance gene, derived from $T$. intermedium (14).

DNA extraction. Wheat leaf pieces (approximately 3 by $1 \mathrm{~cm}$ each) were placed in individual 15-ml tubes and lyophilized overnight. The tissue in each tube was pulverized by vigorous abrasion with acidwashed sand $(2 \mathrm{ml}$ of sand per tube and 5 min of agitation on a commercial paint shaker), then extracted with $6 \mathrm{ml}$ of DNA extraction buffer $(0.1 \mathrm{M}$ Tris- $\mathrm{HCl}, \mathrm{pH} 8.7$; $0.05 \mathrm{M}$ EDTA, $\mathrm{pH} 8.0 ; 1.5 \mathrm{M} \mathrm{NaCl}$; and $1 \%$ cetyltrimethylammonium bromide) to which $30 \mu \mathrm{l}$ of proteinase $\mathrm{K}(10 \mathrm{mg} / \mathrm{ml}$ in Tris-EDTA buffer, $\mathrm{pH}$ 7.6; Tris-EDTA buffer is $10 \mathrm{mM}$ Tris- $\mathrm{HCl}, \mathrm{pH} \mathrm{7.6}$, and 1 $\mathrm{mM}$ EDTA) and $660 \mu \mathrm{l}$ of $20 \%(\mathrm{wt} / \mathrm{vol})$ sodium dodecyl sulfate were added ( $2 \mathrm{~h}$ of incubation at $65^{\circ} \mathrm{C}$ in a water bath), followed by addition in a fume hood of $6 \mathrm{ml}$ of chloroform/isoamyl alcohol (24:1). After slow shaking for $30 \mathrm{~min}$, the tubes were centrifuged at $5,000 \times g$ for $10 \mathrm{~min}$. The supernatant (approximately $3 \mathrm{ml}$ ) from each tube was removed to a fresh tube and $3 \mathrm{ml}$ of ice-cold isopropanol was added. The DNA which precipitated at the interface between the two phases was removed $(1 \mathrm{ml})$ to a microcentrifuge tube, then pelleted by centrifugation at 15,000 $\times g$ for $20 \mathrm{~min}$. After washing with $70 \%$ (vol/vol) ethanol, DNA pellets were left in $70 \%$ ethanol overnight at $-20^{\circ} \mathrm{C}$, centrifuged at $15,000 \times g$ for $20 \mathrm{~min}$, and the ethanol decanted. The pellets were allowed to air dry; then, each pellet was dissolved in $250 \mu \mathrm{l}$ of autoclaved, deionized water.

Amplification of marker DNA by polymerase chain reaction. Amplifications of the 241-bp J15 marker DNA sequence were carried out using a polymerase chain reaction (PCR) DNA amplification kit (cat. no. N808-0130; Perkin Elmer-Roche Diagnostics, Nutley, NJ.) and the custom primers: left primer $\left(5^{\prime}-3^{\prime}\right)$ GTA GCA GGG GAA GCT GAA GA and right primer $\left(5^{\prime}-3^{\prime}\right)$ CCG AGC TCA CAC GCT AAT TT $(10 \mathrm{pg} / \mu \mathrm{l})$. From the kit, the following reagents were added to a microcentrifuge tube: $32 \mu \mathrm{l}$ of deionized water, 7.5 $\mu \mathrm{l}$ of reverse-transcription PCR buffer, $5 \mu \mathrm{l}$ of $\mathrm{MgCl}_{2}$, and $5 \mu \mathrm{l}$ of $10 \times$ dNTPs. To this mixture, $2.5 \mu \mathrm{l}$ of each of the left and right primer DNA, $1 \mu \mathrm{l}$ of the target DNA sample, and $0.75 \mu$ of Taq DNA polymerase ( 5 units $/ \mu \mathrm{l})$ were added. After mixing the reagents by gently flicking each microcentrifuge tube, thermal cycling was carried out in a PTC 100-MJ thermocycler (MJ Research, Watertown, MA): $3 \mathrm{~min}$ at $94^{\circ} \mathrm{C}$; followed by 34 cycles of $1 \mathrm{~min}$ at $94^{\circ} \mathrm{C}, 1$ min at $60^{\circ} \mathrm{C}$, and 2 min at $72^{\circ} \mathrm{C}$; a 10 -min period of annealing at $72^{\circ} \mathrm{C}$; and concluding with cooling overnight at $4^{\circ} \mathrm{C}$.

PCR DNA products were analyzed in a $1.5 \%$ agarose gel containing ethidium bromide (1). The PCR product $(10 \mu \mathrm{l})$ was mixed with $1.5 \mu \mathrm{l}$ of PCR Loading Buffer (Perkin Elmer-Roche Diagnostics) and loaded into the gel, and electrophoresis was conducted for $2 \mathrm{~h}$ at $40 \mathrm{~V}$. The presence or absence of the J15 SCAR DNA marker was noted compared with the 241bp single band produced by the PCR reaction with DNA extracted from the positive control wheat lines, CI15092 and KS96H10-3.

Temperature and virus isolate interactions for KS03HW12 WSMV resistance. The panel of WSMV isolates used to mechanically inoculate KS03HW12 and Tomahawk wheat comprised LG92, CM93, El Batán 3 (EB 3), ND, WO93, and IHC. They were chosen for the differential reactions they induce, as observed in the wheat line CO960293 (10). Wheat seed were planted in two $30-$ by-50-cm soilfilled metal flats, each with six rows, so that one flat was planted with Tomahawk

Table 1. Coding, origin, isolation host, and year of isolation of Wheat streak mosaic virus (WSMV) isolates

\begin{tabular}{lccc}
\hline WSMV isolate & Location of origin & Isolation host & Year isolated \\
\hline CM93 & Kansas & Wheat & 1993 \\
El Batán 3 & Mexico & Wheat & 1996 \\
IHC & Canada & Wheat & 1989 \\
LG92 & Kansas & Wheat & 1992 \\
ND & North Dakota & Wheat & 1969 \\
Sidney 81 & Nebraska & Wheat & 1981 \\
WO93 & Ohio & Maize & 1993 \\
\hline
\end{tabular}

and the other planted with KS03HW12 wheat. Each row of plants was inoculated with the appropriate isolate (as described above) at the single-leaf stage. The two flats were placed at $18^{\circ} \mathrm{C}$ for 3 weeks and then moved to $24^{\circ} \mathrm{C}$ for an additional 2 weeks. After 3 weeks at $18^{\circ} \mathrm{C}$, the plants were rated for symptoms and the third leaf was harvested from each plant and bulked within a row inoculated with a given WSMV isolate and a 1:5 wt/vol dilution of extract was prepared (as described above). The extract was used to inoculate Tomahawk wheat seedlings planted 7 days previously. Following 2 weeks of incubation at $24^{\circ} \mathrm{C}$, the fourth leaves of plants that had been inoculated with a WSMV isolate were bulked and separately used to make a $1: 5 \mathrm{wt} / \mathrm{vol}$ dilution of extract. From this preparation, serial dilutions of 1:25, 1:125, and 1:625 were prepared. These extracts were used to mechanically inoculate Tomahawk wheat seedlings planted 1 week previously. The inoculated Tomahawk wheat infectivity assay plants were held in a greenhouse under natural lighting (temperatures ranged from 19 to $28^{\circ} \mathrm{C}$ ) for 2 weeks and then rated for numbers of symptomatic plants. The experiment was repeated three times.

Infectivity percentage data were transformed with the arcsine transformation before analysis of variance because the differences among treatments were greater than 40 percentage points (4); untransformed data are presented. The ANOVA for the data was conducted using SAS and significant treatment effects were determined using the LSD at $P=0.05$.

Yield trials. Yield trials in the field compared three sources of WSMV resistance: (i) KS03HW12; (ii) KS96HW10-3, whose resistance derives from $T$. intermedium (9); and (iii) RonL, derived from C0960293 (10). Wheat cultivars with different levels of susceptibility to WSMV infection were included: cvs. 2145, Jagger, and Trego. A randomized complete block experimental design was used for each of the 2 years of field trials, with each treatment replicated four times. Plots (healthy or infected for each cultivar) consisted of three rows, $2.9 \mathrm{~m}$ long with a $0.3-\mathrm{m}$ row spacing, seeded at 50 $\mathrm{kg} / \mathrm{ha}$. Planting was done on 29 September 2004 and 4 October 2005. Plants were inoculated with the Sidney 81 isolate at the two- to three-leaf stage on 19 October 2005 and 25 October 2005 using an airblast inoculation technique (5). Harvest dates were 20 June 2005 and 13 June 2006 , respectively. The ANOVA was conducted using SAS and significant treatment effects were identified using the LSD at $P=0.05$.

\section{RESULTS}

WSMV infectivity testing of KS03HW12, parental, and other wheat lines. Only the wheat lines KS97HW131, 
KS96HW100-5, and Triumph 64 developed symptoms when held at $18^{\circ} \mathrm{C}$ and were infective (Table 2). Significant differences were noted in date of first symptom expression among wheat lines, with Triumph 64 having the earliest and 96HW100-5 the latest symptom expression. No significant difference in virus titer among the symptomatic lines was observed at any of the plant dilutions used in the infectivity assays. RonL, KS03HW12 (2004) KS97HW29, CO960293, KS03HW12-1, KS03HW12-4, and KS03HW126 were not infective.

At $24^{\circ} \mathrm{C}$, all of the wheat lines were infected and developed symptoms and were infective at all dilutions (Table 3). Significant differences were noted in date of first symptom expression among wheat lines, with KS97HW131 having the earliest and CO960293 the latest symptom expression. No significant difference in virus titer was demonstrated among the wheat lines at any of the plant dilutions used in the infectivity assays.

Wsm1 gene probe. Analysis of the chromosome 4A substitution line CI15092 and the chromosome 4-DL translocation line KS96HW10-3 contained identical 241-bp SCAR markers (data not shown). By contrast, the SCAR band was not detected in PCR amplifications of DNA extracts of KS03HW12-6.

Temperature and WSMV isolate interactions for KS03HW12 WSMV resistance. At $18^{\circ} \mathrm{C}$, extracts from KS03HW12 were not infective following inoculation by any of the six WSMV isolates. However, Tomahawk wheat held at the same temperature developed symptoms and extracts prepared from this wheat line were infective (Table 4).

Significant difference in the number of infected plants was observed between EB3 and WO93 at all dilutions, with WO93 having the lowest infection rates. Among the other isolates, differences were noted only at the 1:625 dilution.

At $24^{\circ} \mathrm{C}$, all virus isolates infected both KS03HW12 and Tomahawk wheat and were infective at all plant dilutions to Tomahawk wheat (Table 5). When comparing virus isolates within the KS03HW12 wheat, the WO93 isolate infected significantly fewer wheat plants at the 1:125 dilution, and WO93, EB3, and ND isolates infected fewer wheat plants at the 1:625 dilution, but were not different from each other. For Tomahawk wheat, only the 1:625 dilution showed significant differences among the isolates, with the CM93 isolate infecting the most plants and being different from the ND isolate, which infected the lowest numbers of plants. Extracts prepared from KS03HW12 infected by the CM93 and WO93 isolates of WSMV infected significantly fewer plants at the 1:625 dilution when compared with the same dilution prepared from Tomahawk wheat.
Yield trials. During 2005, the yields of inoculated plants in plots of 2145, Jagger, and Trego wheat were significantly lower than their healthy counterparts (Table 6). For the other wheat lines, no significant differences were observed between healthy and inoculated plots. The same results were observed for the volume weight measurements for each wheat line. In 2006, all yield measurements were reduced because of drought conditions; however, the same results were obtained for the yield and volume weight measurements of 2145, Jagger, and Trego. And again, as in
2005, for the other wheat lines, no significant differences were observed between healthy and inoculated plots.

\section{DISCUSSION}

The WSMV resistance observed for KS03HW12 in the initial greenhouse tests was confirmed and the source identified. In the growth chamber studies, we observed that KS03HW12 did not develop symptoms at $18^{\circ} \mathrm{C}$ (Table 2). This was observed for KS97HW29, one of its pedigree parents, but not for the other two parental lines, KS97HW131 or KS97HW100-5. Evi-

Table 2. Average days postinoculation of first symptom expression (FSE) for different wheat lines and the average percentages of Tomahawk wheat assay plants infected using different dilutions of plant extract prepared from the wheat lines infected by Sidney 81 isolate of Wheat streak mosaic virus when grown at $18^{\circ} \mathrm{C}$

\begin{tabular}{lcrrrr}
\hline & & \multicolumn{4}{c}{ Reciprocal of plant dilution } \\
\cline { 3 - 6 } Wheat lines & FSE $^{\mathbf{y}}$ & \multicolumn{1}{c}{$\mathbf{5}$} & $\mathbf{2 5}$ & $\mathbf{1 2 5}$ & $\mathbf{6 2 5}$ \\
\hline RonL & $\mathrm{NS}^{\mathrm{z}}$ & $0.0 \mathrm{D}$ & $0.0 \mathrm{D}$ & $0.0 \mathrm{D}$ & $0.0 \mathrm{D}$ \\
KS97HW131 & $13.5 \mathrm{~B}$ & $100.0 \mathrm{~A}$ & $100.0 \mathrm{~A}$ & $92.5 \mathrm{AB}$ & $27.5 \mathrm{C}$ \\
KS03HW12 (2004) & $\mathrm{NS}$ & $0.0 \mathrm{D}$ & $0.0 \mathrm{D}$ & $0.0 \mathrm{D}$ & $0.0 \mathrm{D}$ \\
KS97HW29 & $\mathrm{NS}$ & $0.0 \mathrm{D}$ & $0.0 \mathrm{D}$ & $0.0 \mathrm{D}$ & $0.0 \mathrm{D}$ \\
KS96HW100-5 & $15.2 \mathrm{~A}$ & $100.0 \mathrm{~A}$ & $100.0 \mathrm{~A}$ & $80.0 \mathrm{~B}$ & $23.3 \mathrm{C}$ \\
Triumph 64 & $12.0 \mathrm{C}$ & $100.0 \mathrm{~A}$ & $100.0 \mathrm{~A}$ & $82.6 \mathrm{~B}$ & $26.7 \mathrm{C}$ \\
CO960293 & $\mathrm{NS}$ & $0.0 \mathrm{D}$ & $0.0 \mathrm{D}$ & $0.0 \mathrm{D}$ & $0.0 \mathrm{D}$ \\
KS03HW12-1 & $\mathrm{NS}$ & $0.0 \mathrm{D}$ & $0.0 \mathrm{D}$ & $0.0 \mathrm{D}$ & $0.0 \mathrm{D}$ \\
KS03HW12-4 & $\mathrm{NS}$ & $0.0 \mathrm{D}$ & $0.0 \mathrm{D}$ & $0.0 \mathrm{D}$ & $0.0 \mathrm{D}$ \\
KS03HW12-6 & $\mathrm{NS}$ & $0.0 \mathrm{D}$ & $0.0 \mathrm{D}$ & $0.0 \mathrm{D}$ & $0.0 \mathrm{D}$ \\
\hline
\end{tabular}

y FSE and percentage values are averages of three experiments. Treatments not having the same letter in common are significantly different using the least significance difference test $(P=0.05)$.

${ }^{\mathrm{z}} \mathrm{NS}=$ no symptoms in these lines or cultivars during the experiment.

Table 3. Average days postinoculation of first symptom expression (FSE) for different wheat lines and the average percentages of Tomahawk wheat assay plants infected using different dilutions of plant extract prepared from the wheat lines infected by the Sidney 81 isolate of Wheat streak mosaic virus when grown at $24^{\circ} \mathrm{C}$

\begin{tabular}{lrcccl}
\hline & & \multicolumn{4}{c}{ Reciprocal of plant dilution } \\
\cline { 3 - 6 } Wheat lines & FSE $^{\mathbf{z}}$ & $\mathbf{5}$ & $\mathbf{2 5}$ & $\mathbf{1 2 5}$ & $\mathbf{6 2 5}$ \\
\hline RonL & $9.4 \mathrm{~B}$ & $100.0 \mathrm{~A}$ & $100.0 \mathrm{~A}$ & $78.5 \mathrm{ABC}$ & $50.5 \mathrm{EF}$ \\
KS97HW131 & $6.0 \mathrm{C}$ & $100.0 \mathrm{~A}$ & $90.0 \mathrm{AB}$ & $72.5 \mathrm{BCD}$ & $40.5 \mathrm{EF}$ \\
KS03HW12 (2004) & $10.6 \mathrm{~B}$ & $100.0 \mathrm{~A}$ & $100.0 \mathrm{~A}$ & $76.6 \mathrm{AB}$ & $48.9 \mathrm{EF}$ \\
KS97HW29 & $7.7 \mathrm{C}$ & $100.0 \mathrm{~A}$ & $100.0 \mathrm{~A}$ & $86.7 \mathrm{AB}$ & $35.3 \mathrm{EF}$ \\
KS96HW100-5 & $6.1 \mathrm{C}$ & $100.0 \mathrm{~A}$ & $100.0 \mathrm{~A}$ & $83.3 \mathrm{AB}$ & $44.2 \mathrm{EF}$ \\
Triumph 64 & $6.3 \mathrm{C}$ & $100.0 \mathrm{~A}$ & $100.0 \mathrm{~A}$ & $83.3 \mathrm{AB}$ & $29.5 \mathrm{EF}$ \\
CO960293 & $13.7 \mathrm{~A}$ & $100.0 \mathrm{~A}$ & $100.0 \mathrm{~A}$ & $86.6 \mathrm{AB}$ & $15.5 \mathrm{EF}$ \\
KS03HW12-1 & $9.7 \mathrm{~B}$ & $100.0 \mathrm{~A}$ & $100.0 \mathrm{~A}$ & $76.6 \mathrm{AB}$ & $53.3 \mathrm{CDE}$ \\
KS03HW12-4 & $10.5 \mathrm{~B}$ & $100.0 \mathrm{~A}$ & $100.0 \mathrm{~A}$ & $93.3 \mathrm{AB}$ & $46.2 \mathrm{DE}$ \\
KS03HW12-6 & $10.3 \mathrm{~B}$ & $100.0 \mathrm{~A}$ & $93.3 \mathrm{AB}$ & $70.0 \mathrm{BCD}$ & $25.5 \mathrm{EF}$ \\
\hline
\end{tabular}

${ }^{\mathrm{z}}$ FSE and percentage values are averages of three experiments. Treatments not having the same letter in common are significantly different using the least significance difference test $(P=0.05)$.

Table 4. Average percentages of Tomahawk wheat assay plants infected using different dilutions of plant extract prepared from Tomahawk wheat infected by different Wheat streak mosaic virus isolates when grown at $18^{\circ} \mathrm{C}^{\mathrm{y}}$

\begin{tabular}{lrrrrrr}
\hline & \multicolumn{7}{c}{ Virus isolate $^{\mathbf{z}}$} \\
\cline { 2 - 7 } Reciprocal of plant dilution & EB3 & CM93 & ND & LG92 & WO93 & IHC \\
\hline 25 & $100 \mathrm{~A}$ & $100 \mathrm{~A}$ & $100 \mathrm{~A}$ & $100 \mathrm{~A}$ & $70 \mathrm{BC}$ & $100 \mathrm{~A}$ \\
125 & $93 \mathrm{~A}$ & $100 \mathrm{~A}$ & $100 \mathrm{~A}$ & $100 \mathrm{~A}$ & $23 \mathrm{E}$ & $97 \mathrm{~A}$ \\
625 & $47 \mathrm{D}$ & $77 \mathrm{~B}$ & $80 \mathrm{~B}$ & $67 \mathrm{BCD}$ & $0 \mathrm{~F}$ & $53 \mathrm{CD}$ \\
\hline
\end{tabular}

y Values are averages of three experiments. Treatments not having the same letter in common are significantly different using the least significance difference test $(P=0.05)$.

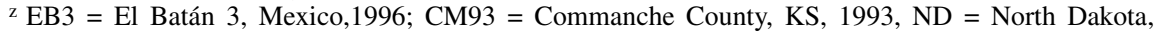
1969; LG92 = Logan County, KS 1992, WO93 = Wooster, OH, 1993, and IHC = Indian Head, Canada, 1989 . 
dently, the temperature-sensitive resistance source was derived from KS97HW29. Before observing the WSMV resistance in KS03HW12, we had not previously tested KS97HW29 in WSMV resistance trials. In turn, the source of the temperaturesensitive resistance in KS03HW29 to WSMV is unknown; however, it is likely that it came from a single plant selected from a broad-based, randomly mated population made by Stan Cox in 1988 at Hutchinson, KS and was identified during a WSMV epiphytotic. Seed of the parental lines of KS97HW29 are no longer available. We observed that resistance from crosses with KS03HW12 is readily inherited in progeny crosses with the parent, but we have not yet characterized the genetics of this temperature-sensitive resistance.

The wheat line CO960293 and cv. RonL, which was selected from the cross CO960293/Trego, were included as resistant controls because CO960293 previously has been demonstrated to have resistance to WSMV $(2,10)$. These two wheat lines also were resistant to WSMV infection at $18^{\circ} \mathrm{C}$, as expected. Triumph 64 was symptomatic at both 18 and $24^{\circ} \mathrm{C}$, as expected. Triumph 64 has been shown to have tolerance to WSMV (8).

The temperature-sensitive resistance to WSMV identified in KS96HW10-3 is derived from $T$. intermedium (9). Our tests found no J15 (SCAR) DNA marker in KS03HW12-6 but consistently detected this marker in KS96HW10-3 and in CI15092, a T. intermedium 4A substitution line (14). Thus, the temperature-sensitive resistance of $\mathrm{KS} 03 \mathrm{HW} 12$ is not likely derived from an accidental out-cross with KS96HW10-3.

The WSMV resistance of KS03HW12 was effective against the six WSMV isolates used in the $18^{\circ} \mathrm{C}$ growth chamber experiments (Table 4). The KS03HW12 plants held at $18^{\circ} \mathrm{C}$ following inoculation with the Sidney 81 isolate (Table 2) or the EB3, CM93, ND, LG92, WO93, and IHC isolates (Table 4) were symptomless and none of the extracts prepared from these plants were infective in backassay to Tomahawk wheat. This was expected because symptomless plants of other tem- perature-sensitive sources (KS96HW10-3 and CO960293) of resistance to WSMV have given the same results $(9,10)$. As expected, the resistance was not effective at a constant temperature of $24^{\circ} \mathrm{C}$. This also has been observed for KS96HW10-3 (9) and CO960293 (10). We observed in previous studies that none of these WSMV isolates could defeat the resistance of $\mathrm{C} 0960293$ at $18^{\circ} \mathrm{C}$ (10). These isolates were chosen for these studies because each was isolated from a different geographic region or represents a different clade or subclade of WSMV isolates based on nucleotide polymorphisms (13). The EB3 and W093 isolates both showed significant reductions in numbers of infected plants at $18^{\circ} \mathrm{C}$ in Tomahawk wheat (Table 4), and each represents a different clade (13). In addition, EB3, which was isolated in Mexico (6), is the most distantly related of the isolates, and its sequence varies from that of the Sidney 81 isolate by $20 \%$ (13).

Symptoms were observed neither for plants in the KS03HW12 field plots nor for the RonL and KS96HW10-3 control plots during the fall or in the spring in the 2 years of the field trials. This correlates well with the lack of significant yield reduction in the KS03HW12 selections and for the RonL and KS96HW10-3 controls. RonL and KS96HW10-3 have good field resistance to WSMV (10). The susceptible lines showed symptoms in the fall and in the spring and all demonstrated significant reductions in yield and volume weight measurements in the inoculated plots.

These results demonstrate that the temperature-sensitive resistance found in $\mathrm{KS} 03 \mathrm{HW} 12$ is effective in growth chamber trials at $18^{\circ} \mathrm{C}$ and is effective in the field under WSMV pressure. The temperaturesensitive resistance also was shown to be stable against all six WSMV isolates representing different geographic regions or clades that were used under growth chamber testing. The resistance source in KS97HW29 parent is unknown. However, our data show that KS03HW12, selected from crosses with KS97HW29, provides an effective source of temperaturesensitive resistance to WSMV in addition to the two sources previously identified $(2,9,10)$

\section{ACKNOWLEDGMENTS}

We thank J. Ackerman for expertise and assistance in conducting the different experiments used in this study; C. Seaman for expertise and assistance in field planting, harvesting, and data analyses; and B. Gillis and M. Budzinsky for their assistance in carrying out the DNA marker analyses.

\section{LITERATURE CITED}

1. Haber, S., Rymerson, R. T., Procunier, J. D., Murray, G., and Cvitkovitch, S. E. 1995. Diag-

Table 6. Grain yield and volume weight of wheat cultivars either healthy (H) or infected (I) by Wheat streak mosaic virus over 2 years at Hays, $\mathrm{KS}^{\mathrm{z}}$

\begin{tabular}{|c|c|c|c|c|c|}
\hline \multirow[b]{2}{*}{ Cultivar } & \multirow[b]{2}{*}{ Treatment } & \multicolumn{2}{|c|}{ Yield (kg/ha) } & \multicolumn{2}{|c|}{ Volume weight $\left(\mathrm{kg} / \mathrm{m}^{3}\right)$} \\
\hline & & 2005 & 2006 & 2005 & 2006 \\
\hline 2145 & $\mathrm{H}$ & $5,014 \mathrm{DE}$ & $1,997 \mathrm{BC}$ & $797 \mathrm{CDE}$ & $706 \mathrm{CD}$ \\
\hline 2145 & $\mathrm{I}$ & $2,726 \mathrm{G}$ & $1,547 \mathrm{D}$ & $704 \mathrm{H}$ & $666 \mathrm{~F}$ \\
\hline KS03HW12-6 & $\mathrm{H}$ & $5,918 \mathrm{AB}$ & $2,363 \mathrm{~A}$ & $800 \mathrm{ABC}$ & $718 \mathrm{~B}$ \\
\hline KS03HW12-6 & I & $5,785 \mathrm{ABC}$ & $2,170 \mathrm{ABC}$ & $800 \mathrm{ABC}$ & $715 \mathrm{BC}$ \\
\hline RonL & $\mathrm{H}$ & $6,114 \mathrm{~A}$ & $2,249 \mathrm{ABC}$ & $803 \mathrm{AB}$ & $756 \mathrm{~A}$ \\
\hline RonL & I & $5,937 \mathrm{AB}$ & $2,265 \mathrm{AB}$ & 807 A & $757 \mathrm{~A}$ \\
\hline Jagger & $\mathrm{H}$ & $5,271 \mathrm{CD}$ & $2,405 \mathrm{~A}$ & $772 \mathrm{E}$ & $698 \mathrm{D}$ \\
\hline Jagger & I & $4,236 \mathrm{~F}$ & $1,970 \mathrm{C}$ & $728 \mathrm{G}$ & $642 \mathrm{G}$ \\
\hline KS96HW10-3 & $\mathrm{H}$ & $4,628 \mathrm{EF}$ & $2,447 \mathrm{~A}$ & $800 \mathrm{ABC}$ & $753 \mathrm{~A}$ \\
\hline KS96HW10-3 & I & $4,374 \mathrm{~F}$ & $2,265 \mathrm{~A}$ & 799 ABC & $751 \mathrm{~A}$ \\
\hline TREGO & $\mathrm{H}$ & 5,476 BCD & $2,178 \mathrm{ABC}$ & 796 BCD & $748 \mathrm{~A}$ \\
\hline TREGO & I & $4,077 \mathrm{~F}$ & $1,511 \mathrm{D}$ & $740 \mathrm{~F}$ & $709 \mathrm{BC}$ \\
\hline $\mathrm{CV}$ & $\ldots$ & 7.9 & 9.5 & 0.8 & 0.9 \\
\hline
\end{tabular}

${ }^{\mathrm{z}}$ Treatments not having the same letter in common are significantly different using the least significance difference test $(P=0.05)$.

Table 5. Average percentages of Tomahawk wheat assay plants infected using different dilutions of plant extract prepared from wheat lines infected by different Wheat streak mosaic virus (WSMV) isolates when grown at $24^{\circ} \mathrm{C}^{\mathrm{x}}$

\begin{tabular}{lccccccc}
\hline & & \multicolumn{5}{c}{ WSMV isolate $^{\mathbf{y}}$} \\
\cline { 3 - 7 } Wheat & Dilution $^{\mathbf{z}}$ & $\mathbf{E B 3}$ & $\mathbf{C M 9 3}$ & $\mathbf{N D}$ & LG92 & WO93 & IHC \\
\hline KS03HW12 & 25 & $100.0 \mathrm{~A}$ & $100.0 \mathrm{~A}$ & $100.0 \mathrm{~A}$ & $100.0 \mathrm{~A}$ & $83.3 \mathrm{~A}$ \\
KS03HW12 & 125 & $96.7 \mathrm{~A}$ & $100.0 \mathrm{~A}$ & $86.6 \mathrm{AB}$ & $100.0 \mathrm{~A}$ & $53.3 \mathrm{CDEF}$ & $100.0 \mathrm{~A}$ \\
KS03HW12 & 625 & $33.3 \mathrm{FGH}$ & $40.0 \mathrm{CDEF}$ & $13.3 \mathrm{GH}$ & $53.3 \mathrm{CDE}$ & $13.3 \mathrm{GH}$ & $46.7 \mathrm{CDEF}$ \\
Tomahawk & 25 & $100 \mathrm{~A}$ & $100.0 \mathrm{~A}$ & $100.0 \mathrm{~A}$ & $100.0 \mathrm{~A}$ & $100.0 \mathrm{~A}$ & $100.0 \mathrm{~A}$ \\
Tomahawk & 125 & $100.0 \mathrm{~A}$ & $100.0 \mathrm{~A}$ & $96.6 \mathrm{~A}$ & $100.0 \mathrm{~A}$ & $100.0 \mathrm{~A}$ & $100.0 \mathrm{~A}$ \\
Tomahawk & 625 & $46.6 \mathrm{EFGH}$ & $66.6 \mathrm{AB}$ & $33.3 \mathrm{DEFG}$ & $56.6 \mathrm{CD}$ & $46.6 \mathrm{CDEF}$ & $60.0 \mathrm{CD}$ \\
\hline
\end{tabular}

${ }^{\mathrm{x}}$ Values are averages of three experiments. Treatments not having the same letter in common are significantly different using the least significance difference test $(P=0.05)$.

${ }^{\text {y }}$ EB3 = El Batán 3, Mexico,1996; CM93 = Commanche County, KS, 1993, ND = North Dakota, 1969; LG92 = Logan County, KS 1992, WO93 = Wooster, OH, 1993, and IHC = Indian Head, Canada, 1989 .

${ }^{\mathrm{z}}$ Reciprocal of plant dilution. 
nosis of flame chlorosis by reverse transcription-polymerase reaction (RT-PCR). Plant Dis. 79:626-630.

2. Haley, S. D., Martin, T. J., Quick, J. S., Seifers, D. L., Stromberger, J. A., Clayshulte, S. R. Clifford, B. L., Peairs, F. B., Rudolph, J. B. Johnson, J. J., Gill, B. S., and Friebe, B. 2002. Registration of CO960293-2 wheat germplasm resistant to Wheat streak mosaic virus and Russian wheat aphid. Crop Sci. 42:1381-1382.

3. Lengkeck, V. H. 1979. Wheat Virus Disease in Southwestern Kansas. Coop. Ext. Rep. Kans. State Univ. Manhattan.

4. Little, T. M., and Hills, R. J. 1978. Transformation. Pages 139-165 in: Agricultural Experimentation: Design and Analysis. T. M. Little and F. J. Hills, eds. John Wiley and Sons, Inc., New York.

5. Martin, T. J., and Hackerott, H. L. 1982. Greenhouse seedling technique to determine the reaction of sorghum to maize dwarf mosaic virus strain A. Crop Sci. 22:1255-1256.

6. Sánchez-Sánchez, H., Henry, M., CárdenasSoriano, E., and Alviso-Villasana, H. F. 2001. Identification of Wheat streak mosaic virus and its vector Aceria tosichella in Mexico. Plant Dis. 85:13-17.

7. Seifers, D. L. 1992. Partial characterization of a Colorado isolate of Agropyron mosaic virus. Plant Dis. 76:564-569.

8. Seifers, D. L., and Martin, T. J. 1988. Correlation of low level of Wheat streak mosaic virus resistance in Triumph 64 wheat with low virus titer. Phytopathology 78:703-707.

9. Seifers, D. L., Martin, T. J., Harvey, T. L., and Gill, B. S. 1995. Temperature sensitivity and efficacy of wheat streak mosaic virus resistance derived from Agropyron intermedium. Plant Dis. 79:1104-1106.

10. Seifers, D. L., Martin, T. J., Harvey, T. L., Haber, S., and Haley, S. D. 2006. Temperature sensitivity and efficacy of Wheat streak mosaic virus resistance derived from CO960293 wheat. Plant Dis. 90:623-628.

11. Sim, T., IV, Willis, W. G., and Eversmeyer, M G. 1988. Kansas plant disease survey. Plant Dis. 72:832-836.

12. Slykuis, J. T. 1955. Aceria tulipae Keifer (Acarina: Eriophyidae) in relation to the spread of wheat streak mosaic. Phytopathology 45:116-128

13. Stenger, D. C., Seifers, D. L., and French, R. 2002. Patterns of polymorphism in Wheat streak mosaic virus: sequence space explored by a clade of closely related viral genotypes rivals that between the most divergent strains. Virology 302:58-70.

14. Talbert, L. E., Bruckner, P. L., Smith, L. Y, Sears, R., Martin, T. J. 1996. Development of PCR markers linked to resistance to Whea streak mosaic virus in wheat. Theor. Appl. Genet. 93:463-467.

15. Willis, W. G. 1981. The 1981 Wheat Streak Mosaic Epidemic in Kansas. Coop. Ext. Rep. Kans. State Univ. Manhattan. 